\title{
Stress and sex: does cortisol mediate sex change in fish?
}

\author{
Alexander Goikoetxea, Erica V Todd and Neil J Gemmell \\ Department of Anatomy, University of Otago, Dunedin, New Zealand \\ Correspondence should be addressed to A Goikoetxea; Email: alexandergoikoetxea@gmail.com
}

\begin{abstract}
Cortisol is the main glucocorticoid (GC) in fish and the hormone most directly associated with stress. Recent research suggests that this hormone may act as a key factor linking social environmental stimuli and the onset of sex change by initiating a shift in steroidogenesis from estrogens to androgens. For many teleost fish, sex change occurs as a usual part of the life cycle. Changing sex is known to enhance the lifetime reproductive success of these fish and the modifications involved (behavioral, gonadal and morphological) are well studied. However, the exact mechanism behind the transduction of the environmental signals into the molecular cascade that underlies this singular process remains largely unknown. We here synthesize current knowledge regarding the role of cortisol in teleost sex change with a focus on two well-described transformations: temperature-induced masculinization and socially regulated sex change. Three non-mutually exclusive pathways are considered when describing the potential role of cortisol in mediating teleost sex change: cross-talk between GC and androgen pathways, inhibition of aromatase expression and upregulation of amh (the gene encoding anti-Müllerian hormone). We anticipate that understanding the role of cortisol in the initial stages of sex change will further improve our understanding of sex determination and differentiation across vertebrates, and may lead to new tools to control fish sex ratios in aquaculture.

Reproduction (2017) 154 R149-R160
\end{abstract}

\section{Introduction}

\section{Teleost fish as models for understanding vertebrate sexual development}

Glucocorticoids (GCs) are an essential component of the hormonal cascade underlying human reproduction (Whirledge \& Cidlowski 2010). Precise levels of GCs are necessary for a balanced gonadal function; and increased cortisol (the most important GC) levels due to stress can cause loss of pregnancy and/or have a negative effect on fertility (Nepomnaschy et al. 2006, Whirledge \& Cidlowski 2010). In recent years, cortisol has been proposed as a key factor linking external environmental stimuli with internal physiological responses during sexual development, whereby environmental stress may initiate a steroidogenic shift at the onset of sex change (Solomon-Lane et al. 2013, Nozu \& Nakamura 2015). However, the exact role of cortisol or stress in transducing the external signals to elicit physiological responses during sexual development and sex change remains a mystery.

Studies in the last few decades have revealed that sexual development is more plastic in non-mammalians, especially teleost fish (reviewed by Devlin \& Nagahama 2002, Avise \& Mank 2009). It has been shown in many teleost species that environmental factors can interact and sometimes override genetic factors to control sexual development. More dramatically, in many marine fish, individuals can change sex as an adaptive response to environmental changes even during adulthood (Kobayashi et al. 2013). Such sensitivity to environmental stimuli may explain why teleost fishes display such highly diverse sex determination and developmental systems, which make them good models for understanding vertebrate sexual development (reviewed by Wilhelm \& Koopman 2006, Matson \& Zarkower 2012, Herpin \& Schartl 2015).

From mounting data in mammalian systems, we now comprehend that there is a direct competition between antagonistic male and female signaling networks. Following activation of one sex-specific network in early development, sexual fate must be actively maintained through ongoing suppression of the opposing network throughout adulthood (Matson et al. 2011, Windley \& Wilhelm 2015). Disruption of this process likely causes disorders of sex development (DSD) (Todd et al. 2016) involving pathologies causing ambiguous genitalia that affect 1 in 4500 live births (Sax 2002). Our understanding of the dysregulation of sexual development that results in various human DSD may be greatly enhanced by elucidating how a usually committed sexual fate remains plastic in sexchanging fish. Here, we review the latest advances in our understanding of the process of sex change in 
teleost fish, highlighting recent research suggesting a key role for stress in mediating temperature-induced masculinization (TIM) and socially regulated sex change. We present a synthesis of previous research regarding the mechanistic role of cortisol in mediating teleost sex change, emphasizing the importance of three key pathways through which cortisol may induce maleness, as originally proposed by Fernandino et al. (2013). We build on previous reviews in this area by incorporating critical recent studies that lend further support to the cortisol hypothesis.

\section{Sex change in teleosts}

Teleost fishes display a diversity of sex determination and developmental systems found in no other vertebrate lineage. They may exhibit gonochorism (fixed separate sexes), simultaneous (or synchronous) or sequential hermaphroditism (Devlin \& Nagahama 2002). Teleost species are the only known vertebrates with sequentially hermaphroditic representatives, which undergo sex change as an adaptive part of the life cycle (Robertson \& Choat 1974, Shapiro 1979). Sequential hermaphroditism has multiple evolutionary origins in fishes, having been reported in 27 taxonomic families spread across nine orders (Munday et al. 2006, Avise \& Mank 2009, Godwin 2009). In such species, the reproductive value is typically strongly size dependent, and sex change enables an individual to maximize the lifetime reproductive fitness by reproducing as one sex while small, and another sex when older and larger (the size advantage model or SAM; Warner 1988). Three strategies are observed: protogynous (female to male, common among coral reef fishes such as groupers, parrotfishes and wrasses), protandrous (male to female, as in anemone fishes) and sequentially bidirectional sex change (sex change in either direction, common in gobies). All three approaches entail modifications to behavior, gonadal restructuring and alterations in external morphology (Warner 1984, Nakamura \& Kobayashi 2005, Godwin 2009). Sex change in teleost fish illustrates a dramatic example of environmentally cued phenotypic plasticity unprecedented in any other group of vertebrates (Frisch 2004, Moczek 2015).

Many commercially valuable fish species naturally change sex (e.g. grouper). In aquaculture settings, artificial control of sex ratios using sex-change technology has become essential for the accomplishment of successful operations (Frisch 2004, Budd et al. 2015). For example, artificial achievement of monosex populations can be valuable for increasing growth rates or to ensure availability of broodstock of a particular sex (Frisch 2004). A molecular-level understanding of sex change, and especially the upstream factors that initiate this process, would enable the development of efficient, low-cost genetic tools for controlling sex ratios, thereby avoiding the use of steroid treatments that pose significant environmental contamination risk.

\section{Sex determination, sex change and the environment}

Sex change involves switching the sexual characteristics associated with one of the sexes (male or female) into those of the opposite one. To fully comprehend this diversity, we need to backtrack to the point at which sexual fate is first decided, sex determination. Sex determination is the regulatory system that determines whether the undifferentiated gonads will form either ovaries or testes, while sex differentiation constitutes the process of gonad development thereafter (Bull 1983, Devlin \& Nagahama 2002). Sex determination encompasses a series of mechanisms that have classically been divided into those having either a genetic or environmental basis. Genetic sex determination (GSD) takes place when the individual's primary sex is determined at fertilization by inherited genetic elements, which are different between males and females (e.g. XX/XY chromosomal sex determination in mammals). Environmental sex determination (ESD) involves sexual fatebeing determined by external environmental conditions experienced during early development (e.g. temperature) (Bull 1983). Nevertheless, increasing evidence challenges this strict GSD-ESD dichotomy. Numerous examples exist where organisms are influenced by both strategies; their phenotypic sex being defined by the interaction between GSD and ESD (Sarre et al. 2004, 2011, Stelkens \& Wedekind 2010, Holleley et al. 2016). Moreover, there are instances where specific external conditions can induce functional sex reversal in otherwise GSD species, an event referred to as environmental sex reversal (ESR) (Shao et al. 2014). Examples of ESR can be found across both invertebrates (as reported in the oviparous oyster Crassostrea virginica; Coe 1943) and vertebrates such as fishes (as seen, under both laboratory and wild conditions, in the pejerrey, Odontesthes bonariensis; Hattori et al. 2009, Yamamoto et al. 2014), reptiles (occurring naturally in the Australian bearded dragon, Pogona vitticeps; Holleley et al. 2015) or amphibians (as observed in wild populations of the frog Rana temporaria; Alho et al. 2010). Herein, the term 'sex change' is used to refer exclusively to the male-to-female or femaleto-male transformation that sequentially hermaphroditic teleost fishes undergo as a usual part of the life cycle. We use the term 'sex reversal', as it is common in the literature, to refer to the process whereby environmental conditions override genetic factors during early stages of development and induce the phenomenon of ESR, as it occurs in fishes, reptiles and amphibians. A range of biotic and abiotic factors, e.g. temperature, social changes, $\mathrm{pH}$, hypoxia, relative density, pathogens, etc., have been reported to act as environmental cues for ESR (reviewed by Devlin \& Nagahama 2002, Stelkens \& Wedekind 2010). Of these, water temperature and 
social factors have been the most extensively studied (Warner 1984, Ospina-Alvarez \& Piferrer 2008, Godwin 2009, Kato et al. 2011, Ribas et al. 2017). Studies on temperature sex determination (a type of ESD) in fish constitute a great example of the interaction and blurred lines between the false GSD-ESD dichotomy, showing that the production of cortisol as a result of thermal stress can lead to masculinization of female fish under artificial conditions, in a transformation known as TIM. Recent research suggests that in addition to possibly mediating TIM, cortisol may similarly act as a key physiological signal underlying sex change in sequential hermaphroditic fish, which most often occurs in response to a change in social circumstances (Nozu \& Nakamura 2015).

\section{The role of cortisol}

\section{Cortisol as a transducer of thermal and social cues}

Elevated temperatures have been shown to cause gonadal masculinization by inhibiting ovarian development in several gonochoristic species under artificial conditions (Hattori et al. 2009, Hayashi et al. 2010, Yamaguchi et al. 2010, Fernandino et al. 2012, Yamaguchi \& Kitano 2012, reviewed by Fernandino et al. 2013). Stressful conditions can affect many steroidogenic enzymes during maturation of the gametes, and several authors have emphasized the role of GCs in influencing gonadal fate during TIM (Hattori et al. 2009, Hayashi et al. 2010,
Yamaguchi et al. 2010). Furthermore, recent studies have also reinforced the hypothesis of stress (i.e. plasma levels of cortisol) being associated with sex change in sequential hermaphrodites induced by social interactions (Table 1) (Godwin \& Thomas 1993, Perry \& Grober 2003, SolomonLane et al. 2013, Nozu \& Nakamura 2015). Protogynous, protandrous and bidirectional sex changes in sequential hermaphrodites are thought to be mediated by factors that control steroidogenic gene expression and regulate agonistic behavior and social status. Socially induced sex change depends both on the physical status of the fish and on the appropriate social conditions to occur (Munday et al. 2006, Lamm et al. 2015). In protogynous species, for example, this involves loss of a dominant male from a social group of females leading to the sex change of the dominant alpha female (Robertson \& Choat 1974, Jones \& Thompson 1980, Warner \& Swearer 1991). It remains unanswered whether differential stress responsiveness is a cause or a consequence of the individual's social rank (Øverli et al. 1999). However, it has been shown that the hypothalamic-pituitaryinterrenal or HPI axis (homologous to the hypothalamicpituitary-adrenal or HPA axis) response and subsequent cortisol production cascade are indeed influenced by social status (Øverli et al. 1999) and could affect sexual fate (Iwata et al. 2012).

The exact ways in which cortisol may act as a mediator in the masculinization process remain unclear, although several hypotheses exist (reviewed by Baroiller \& D'Cotta 2016, Todd et al. 2016, Liu et al. 2017). One

Table 1 Summary of current knowledge regarding the involvement of cortisol in the processes of temperature-induced masculinization and socially regulated sex change.

\begin{tabular}{|c|c|c|c|c|}
\hline Species & $\begin{array}{l}\text { Reproductive } \\
\text { strategy }\end{array}$ & Induction of sex change & Effects observed & References \\
\hline $\begin{array}{l}\text { Amphiprion melanopus } \\
\text { (cinnamon clownfish) }\end{array}$ & Protandrous & $\begin{array}{l}\text { Removal of dominant } \\
\text { female }\end{array}$ & $\begin{array}{l}\text { Gonadal sex change accompanied by } \\
\text { increase in plasma cortisol levels, } \\
\text { reaching a peak on day } 20 \text { post female } \\
\text { removal }\end{array}$ & Godwin and Thomas (1993) \\
\hline $\begin{array}{l}\text { Halichoeres trimaculatus } \\
\text { (three-spot wrasse) }\end{array}$ & Protogynous & $\begin{array}{l}\text { Prolonged administration } \\
\text { of cortisol }\end{array}$ & $\begin{array}{l}\text { Gonadal sex change accompanied by } \\
\text { reduction in E2 levels }\end{array}$ & Nozu and Nakamura (2015) \\
\hline \multirow[t]{2}{*}{$\begin{array}{l}\text { Lythrypnus dalli } \\
\text { (bluebanded goby) }\end{array}$} & \multirow[t]{2}{*}{ Bidirectional } & $\begin{array}{l}\text { Removal of dominant } \\
\text { male }\end{array}$ & $\begin{array}{l}\text { Female-to-male sex change accompanied } \\
\text { by increase in cortisol levels during } \\
\text { early sex change stages. }\end{array}$ & \multirow[t]{2}{*}{ Solomon-Lane et al. (2013) } \\
\hline & & CRF administration & $\begin{array}{l}\text { Single i.c.v. injection did not cause sex } \\
\text { change }\end{array}$ & \\
\hline $\begin{array}{l}\text { Odontesthes bonariensis } \\
\text { (pejerrey) }\end{array}$ & Gonochoristic & $\begin{array}{l}\text { High temperature and } \\
\text { cortisol administration }\end{array}$ & $\begin{array}{l}\text { Temperature-induced masculinization. } \\
\text { Downregulation of gonadal aromatase } \\
\text { and increased 11KT synthesis }\end{array}$ & $\begin{array}{l}\text { Hattori et al. (2009), Blázquez } \\
\text { and Somoza (2010), } \\
\text { Shinoda et al. (2010), } \\
\text { Fernandino et al. (2011) }\end{array}$ \\
\hline Oryzias latipes (medaka) & Gonochoristic & $\begin{array}{l}\text { High temperature and } \\
\text { cortisol administration }\end{array}$ & $\begin{array}{l}\text { Temperature-induced masculinization. } \\
\text { Downregulation of gonadal aromatase. } \\
\text { Suppression of female-type PGC } \\
\text { proliferation }\end{array}$ & $\begin{array}{l}\text { Hattori et al. (2007), } \\
\text { Selim et al. (2009), } \\
\text { Hayashi et al. (2010) }\end{array}$ \\
\hline $\begin{array}{l}\text { Paralichthys olivaceus } \\
\text { (Japanese flounder) }\end{array}$ & Gonochoristic & $\begin{array}{l}\text { High temperature and } \\
\text { cortisol administration }\end{array}$ & $\begin{array}{l}\text { Temperature-induced masculinization. } \\
\text { Downregulation of gonadal aromatase. } \\
\text { Delay in start of germ cell proliferation }\end{array}$ & $\begin{array}{l}\text { Kitano et al. (1999), } \\
\text { Yamaguchi et al. (2010), } \\
\text { Yamaguchi \& Kitano (2012) }\end{array}$ \\
\hline $\begin{array}{l}\text { Parapercis cylindrica } \\
\text { (sandperch) }\end{array}$ & Protogynous & $\begin{array}{l}\text { Cortisol administration } \\
\text { and removal of } \\
\text { dominant male }\end{array}$ & $\begin{array}{l}\text { Cortisol-treated fish changed sex, as did } \\
\text { all sham-treated and control fish }\end{array}$ & Frisch et al. (2007) \\
\hline
\end{tabular}

Modified from Fernandino et al. (2013).

$11 \mathrm{KT}, 11$-ketotestosterone; CRF, corticotropin-releasing factor; E2, 17 $\beta$-estradiol; i.c.v., intracerebroventricular; PGC, primordial germ cell. 
of the first published reports of the association between stress and sequential hermaphroditism in a teleost fish was for socially induced sex change in the protandrous cinnamon clownfish (Amphiprion melanopus) in which serum cortisol levels were observed to peak in the later sex change stages (Godwin \& Thomas 1993). Perry and Grober (2003) suggested that environmental stimuli affect cortisol levels which, in turn, modulate brain activity, effectively providing a mechanism for communication between the brain and the gonads (Perry \& Grober 2003, Blázquez \& Somoza 2010). According to Perry and Grober (2003), dominant males in social groups of protogynous species were responsible for inhibiting socially induced sex change of subordinate females through their aggressive behavior, and the release from this high stress (i.e. drop in cortisol) would trigger the sex change of the alpha female, which would, in turn, keep the cortisol levels of the rest of the females elevated.

Furthermore, Perry and Grober (2003) also proposed another hypothesis stating that GCs could act as modulators of transcription as well as regulators of steroid production directing the function of $11 \beta$-hydroxylase (Cyp11b) and 11 -hydroxysteroid dehydrogenase (Hsd11b) enzymes through substrate competition with androgens testosterone ( $\mathrm{T}$ ) and 11-ketotestosterone (11KT, the most powerful androgen in teleosts). In teleost fish, $\mathrm{T}$ acts as a prohormone, producing either $17 \beta$-estradiol (E2, the most potent estrogen in both teleosts and mammals) through the gonadal or brain aromatase (Cyp19a1a and Cyp19a1b respectively) or $11 \mathrm{KT}$ by Cyp11b and Hsd11b enzymes (Fig. 1) (Frisch 2004). Cyp 11 b and Hsd11b are critical not only for the synthesis of 11-oxygenated androgens, but also for the metabolism of GCs (Perry \& Grober 2003, Alderman \& Vijayan 2012, Fernandino et al. 2012).

However, both the Release from Social Stress and the Substrate Competition for Enzymes hypotheses were refuted by work on the protogynous Parapercis cylindrica (sandperch) in which cortisol implants inserted into the dominant female of a social group neither showed detectable effects on the pattern of steroidogenesis nor inhibited sex change under permissive conditions (i.e. removal of dominant male) (Frisch et al. 2007). Research on gonochoristic pejerrey has also come into conflict with the Substrate Competition for Enzymes hypothesis, since results on pejerrey larvae showed that the cortisol treatment was associated with significant increases in $11 \mathrm{KT}$, but not $\mathrm{T}$, during the first 4 weeks (Hattori et al. 2009). In combination with data from Frisch et al. (2007), an increase in cortisol levels was proposed as part of the trigger initiating sex change in sequential hermaphrodites by Solomon-Lane et al. (2013), who argued that this elevation would increase corticotropinreleasing factor (CRF) signaling and activity of HPI axis. Their work on the bidirectional hermaphrodite Lythrypnus dalli (bluebanded goby) showed that cortisol peaked in early stages of sex change during which differences in $\mathrm{HPI}$ axis activity were also shown to reflect social status (Solomon-Lane et al. 2013). Most recently, long-term cortisol administration was shown to induce sex change in protogynous three-spot wrasse (Halichoeres trimaculatus; Nozu \& Nakamura 2015). These recent studies suggest that elevated cortisol levels should promote, rather than inhibit, protogynous sex change, which is worthy of future investigation.

\section{Cross-talk between hypothalamic-pituitary-gonadal (HPG) and HPI axes}

In all vertebrates, the HPG axis plays a principal role in development and reproduction and is considered the primary signaling pathway by which environmental

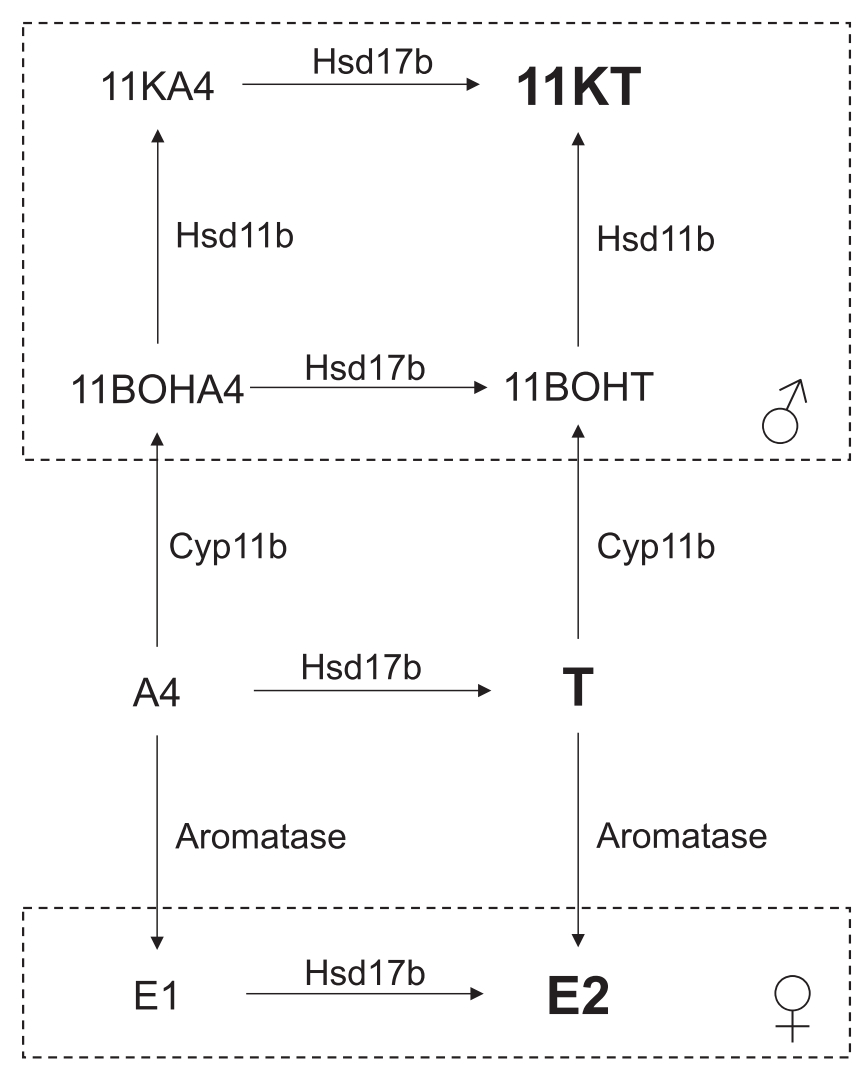

Figure 1 Simplified illustration of steroidogenic pathways relevant to triggering and maintaining sex change in teleost fishes. Contrarily to most vertebrates, higher levels of $\mathrm{T}$ (testosterone) are not directly associated with maleness, and equal levels (or even higher) of T concentrations can be found in female individuals compared to other males (Borg 1994). The balance between 11KT (11-ketotestosterone) and E2 (17 $\beta$-estradiol) influences the differentiation of germ cells into ovaries or testes, but it is still not clear whether androgens and estrogens can redirect the fate of existing germ cells, or if these are replaced by newly proliferated ones (Lo Nostro et al. 2003, Liu et al. 2017). Dashed boxes represent their predominance in male ( $\left.\sigma^{\top}\right)$ and female (o) fishes, respectively. 11BOHA4, 11 $\beta$-hydroxyandrostenedione; 11BOHT, $11 \beta$-hydroxytestosterone; $11 \mathrm{KA} 4$, adrenosterone; A4, androstenedione; Cyp11b, 11 -hydroxylase; E1, estrone; Hsd11b, 11ß-hydroxysteroid dehydrogenase. Adapted from Baroiller et al. (1999) and Liu et al. (2017). 
cues are transduced into behavioral and gonadal sex changes in teleosts (Godwin 2010). The HPI axis, also commonly referred to as the stress axis, affects sexual development and reproduction via its cross-talk with the HPG axis (Fig. 2). It has been speculated that these two axes interact with each other to mediate sex change, but the detailed mechanism remains poorly understood.

The cross-talk between the two axes is exemplified by the effects of signaling molecules associated with neural activity on circulating cortisol, which has been proposed to indirectly regulate gonadal sex change (Liu et al. 2017). These neurotransmitters include norepinephrine $(\mathrm{NE})$, arginine vasotocin (AVT), serotonin (5-HT), dopamine (DA), kisspeptin and melatonin (reviewed by Godwin 2010, Lamm et al. 2015, Liu et al. 2017). $\mathrm{NE}$ is known to influence both the liberation of gonadotropin-releasing hormone $(\mathrm{GnRH})$ and the production of gonadotropins $(\mathrm{GtHs})$ in gonochoristic fish (Chang \& Peter 1984, Yu et al. 1991). Moreover, in mammals, NE has been demonstrated to control CRF neurons (Itoi et al. 1999), and evidence in rainbow trout (Oncorhynchus mykiss) suggests that NE stimulates HPI axis activity (Øverli et al. 2000). Neuropeptide AVT is homologous to mammalian arginine vasopressin and has been the focus of the study of behavioral sex change in fish (Donaldson \& Young 2008). Interestingly, AVT has been shown to increase plasma cortisol levels in rainbow trout (Baker et al. 1996, Gesto et al. 2014), which links cortisol with the transduction of social information. Furthermore, serotonin, which promotes the liberation of $\mathrm{GnRH}$ and mediates the increase of luteinizing hormone (LH) and follicle-stimulating hormone (FSH) levels in gonochoristic fish (Yu et al. 1991, Senthilkumaran et al. 2001), can stimulate or inhibit the HPI axis through different neuronal projections (Lepage et al. 2002). Therefore, the interaction among AVT, NE and 5-HT seems to play an essential role in mediating communication between the brain and the gonads via HPG and HPI axes during sex change (reviewed by Godwin 2010, Lamm et al. 2015).
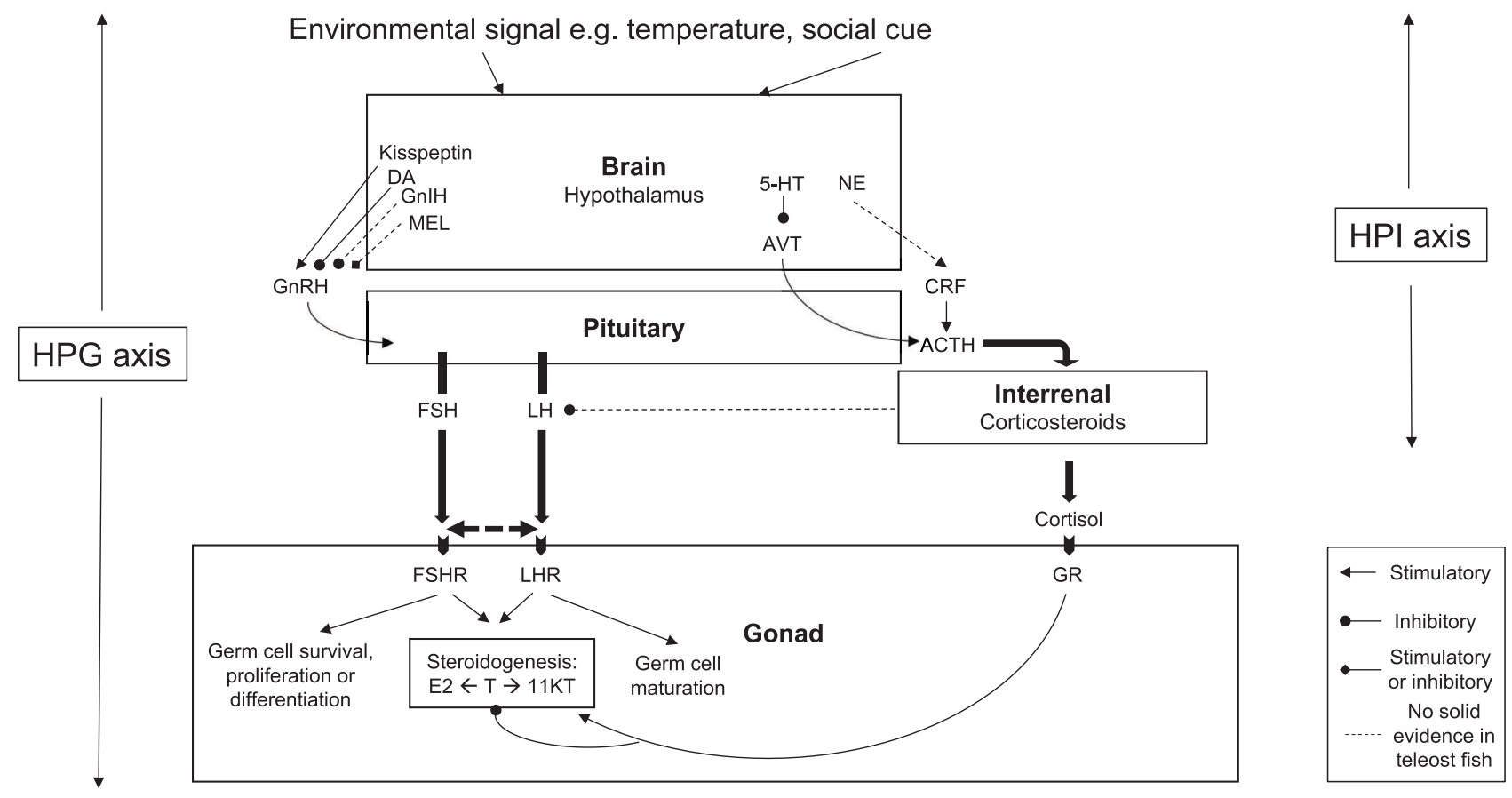

Figure 2 Schematic representation of cross-talk between HPG (Hypothalamic-Pituitary-Gonadal) and HPI (Hypothalamic-Pituitary-Interrenal) axes that regulate steroidogenesis and behavior in teleost fish. HPG axis regulation begins with the Gonadotropin-releasing hormone (GnRH), secreted from the preoptic area (POA) in the hypothalamus by $\mathrm{GnRH}$-expressing neurons, which directly innervate the anterior pituitary (Foran \& Bass 1999). When stimulated by GnRH, the pituitary produces the gonadotropins (GtHs) LH and FSH. Once released into the circulatory system, these gonadotropins mediate the release of sex steroids via their receptors in the gonad, including $17 \beta$-estradiol (E2) and 11-ketotestosterone (11 KT) in the case of teleost fish (Foran \& Bass 1999). Likewise, under a situation of stress, activation of the HPI axis begins in the POA of the hypothalamus, which is stimulated to secrete CRF by CRF neurons, which in turn stimulates corticotrophic cells of the anterior pituitary to release ACTH (also known as corticotropin or adrenocorticotropic hormone) into the blood stream (Wendelaar Bonga 1997). ACTH circulates to the interrenal cells in the head kidney (homologous to the adrenal gland in mammals) where it binds to the melanocortin receptor 2 (also known as the ACTH or MC2 receptor) to activate cortisol synthesis and release (Wendelaar Bonga 1997, Mommsen et al. 1999).

Feedback relationships are not illustrated. Solid lines indicate interactions with support from fish models; dashed lines indicate interactions with support from non-teleost systems that are yet to gain supporting evidence in fish. 5-HT, serotonin; AVT, arginine vasotocin; DA, dopamine; FSHR, follicle-stimulating hormone receptor; GR, glucocorticoid receptor; GnIH, gonadotropin-inhibitory hormone; LHR, luteinizing hormone receptor; MEL, melatonin; NE, norepinephrine; T, testosterone. Modified from Frisch (2004), Todd et al. (2016), Liu et al. (2017). 
A recently proposed hypothesis suggests that increased NE activities in the brain can lead to the rapid increase in serum cortisol levels, while a diminished presence of serotonin annuls the inhibitory effects of this neurotransmitter on AVT signaling, enabling the maintenance of high cortisol levels during the first stages of gonadal sex change (Liu et al. 2017). In addition, novel findings have revealed possible key roles of melatonin of being involved in the synchronization of circadian rhythms, blood pressure regulation and seasonal reproduction (Altun \& Ugur-Altun 2007). Melatonin's response to stressors has been reported in the Mozambique tilapia (Oreochromis mossambicus) in which serum melatonin levels were reported to increase after exposure to high temperatures (Relkin 1989). The effects of melatonin on $\mathrm{GnRH}$ and gonadotropin signaling are thought to be stage dependent and studies suggest that despite discrepancies, a regulatory mechanism initiated by melatonin and NE transiently stimulates $\mathrm{GnRH}$-induced LH release to start sex change. This is followed by indirect suppression of $\mathrm{GnRH}$ and gonadotropin signaling by an increase of cortisol levels and $\mathrm{GnIH}$ (gonadotropin-inhibitory hormone) expression (Khan \& Thomas 1996, Amano et al. 2004, Yuan et al. 2012, Alvarado et al. 2015). Along with these factors, an increase in circulating cortisol could directly suppress cyp 19a1a transcription to arrest estrogen production and female-specific gene expression to promote ovarian degeneration (Liu et al. 2017).

\section{Potential pathways through which cortisol regulates sex change}

Three non-exclusive pathways are considered regarding the role of cortisol in triggering the male pathway: (i) cross-talk between corticosteroid and androgen pathways, (ii) the inhibition of aromatase expression through the binding of cortisol to the glucocorticoid response elements (GRE) in the cyp19a1a promoter and (iii) the depletion of primordial germ cells (PGCs) via upregulation of amh (the gene encoding anti-Müllerian hormone) (reviewed by Fernandino et al. 2013, Todd et al. 2016).

\section{Cross-talk between GC and androgen pathways}

The stress axis has been suggested to influence plasma levels of androgens in both mammals (Viau 2002, Carré \& Mehta 2011) and fish (Godwin \& Thomas 1993, Perry \& Grober 2003, Ozaki et al. 2006, reviewed by Goos \& Consten 2002). In teleosts, an example of this cross-talk is visible through key enzymes Cyp11b and Hsd11b (Fig. 3) (Perry \& Grober 2003, Bury \& Sturm 2007). The physiological roles of these enzymes in the testes are yet to be defined. The metabolism of cortisol to 11-oxygenated androgens in vitro has been proposed in various teleost species (Kime 1978), whereby cortisol would induce spermatogonial mitosis by increasing $11 \mathrm{KT}$ production (Ozaki et al. 2006). This hypothesis was challenged by Schulz (1986), whose results in vitro fitted Kime's concept but questioned its importance in vivo, highlighting the possibility that extragonadal steroid metabolism could confound the observed plasma hormone levels.

Only a handful of studies have directly assessed the effect of cortisol on the androgenic pathway in teleost fish (Consten et al. 2002, Kusakabe et al. 2003, Ozaki et al. 2006, Fernandino et al. 2012). Higher doses of cortisol were first suggested to act on testicular steroidogenesis by competition with enzymes Cyp $11 \mathrm{~b}$ and Hsd11b in the common carp Cyprinus carpio (Consten et al. 2002). The dual role of enzymes involved in both GCs and androgen biosynthesis was later addressed in the rainbow trout (Kusakabe et al. 2003). Interestingly, low doses of cortisol administration were also demonstrated

\section{Cross-talk between glucocorticoid and androgen pathways}
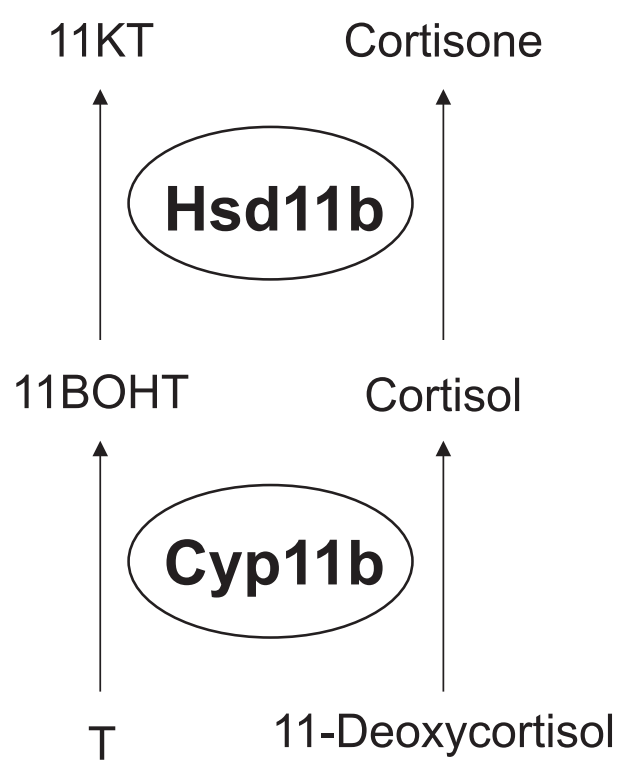

Figure 3 Schematic representing cross-talk between glucocorticoid and androgen pathways. Two types of HSD11B, HSD11B1 and HSD11B2, have been identified and characterized in mammals (Albiston et al. 1994). HSD11B1 converts cortisone to cortisol, while HSD11B2 oxidizes active ligand cortisol to cortisone, the inactive form incapable of binding to glucocorticoid receptors (GRs), thus mediating the stress response (Albiston et al. 1994, Wendelaar Bonga 1997). In fish, however, only one type, Hsd11b2, has been found, although this discovery is limited to a few species. Hsd11 b2 is believed to be the homolog of mammalian HSD11B2 (Baker 2004). Additionally, only one form of Cyp $11 \mathrm{~b}$ has been found in teleosts (Jiang et al. 2003, Kusakabe et al. 2003, Arterbery et al. 2010). $11 \mathrm{BOHT}, 11 \beta$-hydroxytestosterone; $11 \mathrm{KT}$, 11-ketotestosterone;

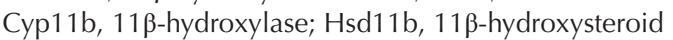
dehydrogenase; T, testosterone. Adapted from Arterbery et al. (2010). 
to induce spermatogenesis and enhance spermatogonial proliferation through the synthesis of $11 \mathrm{KT}$ in vitro in Japanese eel (Anguilla japonica) testis explants (Ozaki et al. 2006). In pejerrey, cortisol treatment during TIM was observed to promote $11 \mathrm{KT}$ synthesis also by modulation of Hsd11 b2 enzyme (Fernandino et al. 2012). Importantly, levels of T and $11 \mathrm{KT}$ were observed to start to elevate prior to the inhibition of gonadal aromatase (cyp19a1a), providing clear evidence of the association between the stress axis and the androgens biosynthesis in the masculinization of larval pejerrey (Hattori et al. 2009, Fernandino et al. 2012). These results suggest that cortisol effects are dose and species specific (reviewed by Fernandino et al. 2013).

\section{Inhibition of aromatase expression}

Another way in which cortisol may tip the balance in favor of androgen production is by directly inhibiting the expression of the aromatase gene, cyp19a1a. Cortisol acts upon the different tissues via its passage through the plasma membrane and subsequent binding to a glucocorticoid receptor (GR), which controls gene expression by binding to GRE within promoter regions of responsive genes (Payvar et al. 1983), such as cyp 19a1a. Aromatase converts androgens to estrogens to maintain ovarian function, and its downregulation is considered a key event initiating female-to-male sex change in fishes (Todd et al. 2016, Liu et al. 2017).

The effects of cortisol on teleost ovarian steroidogenesis were first evaluated in cultured ovarian follicles of rainbow trout, resulting in the suppression of estrogen synthesis (Carragher \& Sumpter 1990). Studies on TIM in Japanese flounder (Paralichthys olivaceus), pejerrey and medaka (Oryzias latipes) have shown downregulation of gonadal aromatase during high temperature-induced sex reversal (Hattori et al. 2009, Yamaguchi et al. 2010, Kitano et al. 2012, Yamaguchi \& Kitano 2012). The masculinizing effects of high temperatures or cortisol can be rescued by $17 \beta$-estradiol treatment, as shown in medaka and Japanese flounder (Kitano et al. 2012). Moreover, cortisol was shown to directly suppress transcription of cyp19a1a in vitro in Japanese flounder by binding to GRE in the gene's promoter region (Yamaguchi et al. 2010, Yamaguchi \& Kitano 2012).

\section{Upregulation of amh, promoting gonadal apoptosis and maleness}

Third, cortisol may promote masculinization by upregulating amh (Hattori et al. 2009, Yamaguchi et al. 2010, Yamaguchi \& Kitano 2012) to induce germ cell apoptosis and promote maleness (reviewed by Pfennig et al. 2015, Todd et al. 2016). Although amh is expressed in both sexes, high levels of amh expression are commonly found in male gonads during fish sex differentiation, which reinforces the involvement of this gene in the promotion of male sex differentiation (reviewed by Pfennig et al. 2015). Cortisol administration has been shown to affect amh transcript levels, except for medaka (Hayashi et al. 2010, Kitano et al. 2012, reviewed by Pfennig et al. 2015). Specifically, it is a reduced ratio of PGCs to somatic cells (SC) in the gonad that is considered to have masculinizing effects. Experimental depletion of germ cells in female gonads is associated with male development of the remaining SC, while an increased number of germ cells correlates with the activation and maintenance of the female phenotype by signaling SC to prevent their activation of the male phenotype (Tanaka et al. 2008, reviewed by Pfennig et al. 2015). Thus, in sex-changing fish, cortisol could link temperature-dependent and social cues to gonadal development while acting on amh, which in turn could play a role at the level of the gonads as a downstream effector to inhibit germ cell proliferation and encourage masculinization (reviewed by Pfennig et al. 2015). The potential for cortisol to act on germ cells is consistent with the discovery of GRs on germ cells (Goos \& Consten 2002). GRs have been identified in Sertoli cells in mammalian testes (Levy et al. 1989) but are yet to be demonstrated in fish. Moreover, cortisol has been proposed to play an antagonizing role to $\mathrm{FSH}$, which indeed inhibits the amh expression (Yamaguchi et al. 2010, reviewed by Pfennig et al. 2015).

Upregulation of amh expression has been observed during TIM in Japanese flounder (Yoshinaga et al. 2004, Kitano et al. 2007, Yamaguchi \& Kitano 2012), Southern flounder (Paralichthys lethostigma; Mankiewicz et al. 2013), Nile tilapia (Oreochromis niloticus; Poonlaphdecha et al. 2013) and pejerrey (Fernandino et al. 2008), and likewise during protogynous sex change in ricefield eel (Monopterus albus) (Hu et al. 2015). Acting as a transcription factor, the Amh protein is also known to directly inhibit the cyp19a1a expression in mammals, and an inverse association between amh and cyp19a1a expression is reported in numerous fishes, including Japanese flounder (Kitano et al. 2007), pejerrey (Fernandino et al. 2008), rainbow trout (Vizziano et al. 2008), southern flounder (Mankiewicz et al. 2013) and zebrafish (Danio rerio; Rodríguez-Marí et al. 2005, Wang \& Orban 2007). Recently, a transcriptome-wide study of protogynous sex change in bluehead wrasse (Thalassoma bifasciatum) found that the expression of amh and its receptor amh2 increased concurrently with a drop in cyp19a1a expression (Liu et al. personal communication). Although a causal relationship cannot be established from these data, these results suggest that amh may have an important role in initiating protogynous sex change by suppressing gonadal aromatase expression and/or activating a male-specific expression pathway.

The three proposed pathways through which cortisol may induce gonadal masculinization under stressful conditions are not mutually exclusive and may, therefore, 
be acting together to promote masculinization, both in TIM and in socially induced sequential hermaphrodites.

\section{Conclusions and future opportunities}

Cortisol has emerged as a key physiological mediator of sex change in teleost fish, which may communicate external environmental signals to adaptive reproductive responses. We synthesize mounting evidence reinforcing the involvement of this hormone in two well-described transformations: TIM and, more recently, socially regulated sex change. The mechanistic role of cortisol in sex change involves three non-mutually exclusive pathways: (i) cross-talk between GC and androgen pathways, (ii) inhibition of aromatase expression to arrest estrogen production and (iii) induction of gonadal apoptosis through the upregulation of amh, which may also influence sex-specific gene expression. However, these hypotheses only address how cortisol can induce maleness. Serum cortisol levels have been shown to fluctuate across protandrous sex change, for example, in cinnamon clownfish (Godwin \& Thomas 1993). We encourage further investigation into the role of cortisol in male-to-female sex change in protandrous, as well as, bidirectional hermaphrodites.

Another fruitful avenue for research will be the potential interaction between cortisol and epigenetic factors influencing sex-specific gene expression during sex change (Deveson et al. 2017). Corticosteroid hormones are known to affect methylation of DNA in different mammalian systems. For instance, hydrocortisone (as hormone cortisol is known when supplied as medication) was observed to induce noticeable changes in the 5-MeCyt (5-Methylcytosine) content in the DNA of the rat liver cells, its effect on the level of DNA methylation being both organ and tissue specific (Vanyushin et al. 1973). In guinea pigs, prenatal exposure to synthetic GCs led to lifelong and potentially transgenerational effects on organ methylation, such as global hypomethylation and deregulated expression of mbd2 (methyl-CpG-binding domain protein 2) and dnmt (DNA methyltransferase) mRNA, as well as changes in HPA function (Dunn et al. 2010, Crudo et al. 2012). These critical changes of the epigenome are associated with a higher risk of tumorigenesis (Szyf 2005). In humans, childhood stress (measured in the form of cortisol) has been linked to a genomewide decrease in DNA methylation (Nätt et al. 2015). Cortisol is yet to be associated with epigenetic changes in teleosts. However, TIM-inducing temperatures are shown to induce DNA methylation changes within gene promoters to influence the expression of key sexpathway genes in several fishes (Navarro-Martín et al. 2011, Zhang et al. 2013, Shao et al. 2014, Sun et al. 2016). For example, during high TIM of the European sea bass (Dicentrarchus labrax), hyper-methylation of cyp19a1a led to downregulation of gonadal aromatase expression causing sex reversal (Navarro-Martín et al. 2011). Hyper-methylation of cyp 19a1a gene promoters was similarly observed in testis of the Japanese flounder (Wen et al. 2014), medaka (Contractor et al. 2004), ricefield eel (Zhang et al. 2013) and zebrafish. Genomewide analysis of methylation and gene expression following TIM in half-smooth tongue sole (Cynoglossus semilaevis) revealed that a change in the methylation state was not limited to the gonadal aromatase gene, but occurred across the entire sex development network (Shao et al. 2014). Most recently, TIM in Nile tilapia was associated with increased methylation levels on various chromosomes (Sun et al. 2016). Given the strong evidence for a mechanistic role for both cortisol and DNA methylation individually in regulating sex-specific gene expression during teleost sex change, and evidence that cortisol can promote epigenetic changes in mammals, their potential interaction during sex change warrants investigation. Special attention might be paid to the possibility that cortisol mediates temperature-induced methylation of the cyp19a1a gene.

In teleost fish, one major impediment when measuring cortisol is that being directly related to stress, an absolute control over its quantification and over the handling of fish is essential not to confound its measurement. Current limitations to studying cortisol as a mediator of sex change include the ability to reliably differentiate males and females in dimorphic species, the seasonality of spawning and the individual variation regarding physical fitness. Additionally, it is not an easy task to determine whether differences in cortisol levels observed between social groups (i.e. dominant vs subordinate) may have a role in the triggering of sex change or merely reflect social status. These hurdles can be at least partly overcome by using standardized protocols and consistent laboratory and field conditions and we encourage further investigation. Genomic technologies offer exciting possibilities of testing the hypotheses related to cortisol's influence on the sex-specific gene expression. For example, whole transcriptome sequencing technology (also known as RNA-seq) now enables rapid characterization of global gene expression in any species without the need for prior genomic resources. This approach has already proven successful in identifying candidate triggers of sex change in the bluehead wrasse (Liu et al. 2015, Liu 2016) and Red Sea clownfish (Casas et al. 2016). Manipulative studies will be a critical next step, and technologies such as nucleofection of cDNAs, siRNA (Ryan et al. 2011), vivo morpholinos (Moulton \& Jiang 2009) and gene editing techniques (Irion et al. 2014) represent promising approaches for targeted induction or suppression of expression of candidate genes implicated in gonadal sex change. Organ explant culture systems could provide a suitable highly controlled in vitro system for such 
manipulations as demonstrated with testes explants of Japanese eel (Ozaki et al. 2006) and in an ovary culture system in the three-spot wrasse (Todo et al. 2008).

\section{Declaration of interest}

The authors declare that there is no conflict of interest that could be perceived as prejudicing the impartiality of this review.

\section{Funding}

This research was supported by a Royal Society of New Zealand Marsden Fund grant (UOO1308) to N J G.

\section{Acknowledgements}

The authors thank the editors of Reproduction for inviting them to contribute to this article. The authors are also grateful to $\mathrm{Dr}$ Hui Liu, Dr Tamsin Braisher and three anonymous reviewers for their constructive feedback that helped to improve the final manuscript.

\section{References}

Albiston AL, Obeyesekere VR, Smith RE \& Krozowski ZS 1994 Cloning and tissue distribution of the human 1 I $\beta$-hydroxysteroid dehydrogenase type 2 enzyme. Molecular and Cellular Endocrinology 105 R11-R17. (doi:10.1016/0303-7207(94)90176-7)

Alderman SL \& Vijayan MM 2012 11ß-Hydroxysteroid dehydrogenase type 2 in zebrafish brain: a functional role in hypothalamus-pituitaryinterrenal axis regulation. Journal of Endocrinology 215 393-402. (doi:10.1530/JOE-12-0379)

Alho JS, Matsuba C \& Merilä J 2010 Sex reversal and primary sex ratios in the common frog (Rana temporaria). Molecular Ecology 19 1763-1773. (doi:10.1111/j.1365-294X.2010.04607.x)

Altun A \& Ugur-Altun B 2007 Melatonin: therapeutic and clinical utilization. International Journal of Clinical Practice 61 835-845. (doi:10.1111/j.1742-1241.2006.01191.x)

Alvarado MV, Carrillo M \& Felip A 2015 Melatonin-induced changes in kiss/gnrh gene expression patterns in the brain of male sea bass during spermatogenesis. Comparative Biochemistry and Physiology Part A: Molecular and Integrative Physiology 185 69-79. (doi:10.1016/j. cbpa.2015.03.010)

Amano M, ligo M, Ikuta K, Kitamura S, Okuzawa K, Yamada H \& Yamamori K 2004 Disturbance of plasma melatonin profile by high dose melatonin administration inhibits testicular maturation of precocious male masu salmon. Zoological Science 21 79-85. (doi:10.2108/02890003(2004)21[79:DOPMPB]2.0.CO;2)

Arterbery AS, Deitcher DL \& Bass AH 2010 Divergent expression of 11 $\beta$ hydroxysteroid dehydrogenase and $11 \beta$-hydroxylase genes between male morphs in the central nervous system, sonic muscle and testis of a vocal fish. General and Comparative Endocrinology 167 44-50. (doi:10.1016/j.ygcen.2010.02.021)

Avise JC \& Mank JE 2009 Evolutionary perspectives on hermaphroditism in fishes. Sexual Development 3 152-163. (doi:10.1159/000223079)

Baker ME 2004 Evolutionary analysis of $11 \beta$-hydroxysteroid dehydrogenasetype 1, -type 2, -type 3 and $17 \beta$-hydroxysteroid dehydrogenase-type 2 in fish. FEBS Letters 574 167-170. (doi:10.1016/j.febslet.2004.08.023)

Baker BI, Bird DJ \& Buckingham JC 1996 In the trout, CRH and AVT synergize to stimulate ACTH release. Regulatory Peptides 67 207-210. (doi:10.1016/S0167-0115(96)00130-9)

Baroiller JF \& D'Cotta H 2016 The reversible sex of gonochoristic fish: insights and consequences. Sexual Development 10 242-266. (doi:10.1159/000452362)
Baroiller JF, Guiguen Y \& Fostier A 1999 Endocrine and environmental aspects of sex differentiation in fish. Cellular and Molecular Life Sciences 55 910-931. (doi:10.1007/s000180050344)

Blázquez M \& Somoza GM 2010 Fish with thermolabile sex determination (TSD) as models to study brain sex differentiation. General and Comparative Endocrinology 166 470-477. (doi:10.1016/ j.ygcen.2009.10.004)

Borg B 1994 Androgens in teleost fishes. Comparative Biochemistry and Physiology Part C: Pharmacology, Toxicology and Endocrinology 109 219-245. (doi:10.1016/0305-0491(94)90005-1)

Budd A, Banh Q, Domingos J \& Jerry D 2015 Sex control in fish: approaches, challenges and opportunities for aquaculture. Journal of Marine Science and Engineering 3 329-355. (doi:10.3390/jmse3020329)

Bull JJ 1983 Evolution of Sex Determining Mechanisms. The Benjamin/ Cummings Publishing Company, Inc.: Menlo Park, California, USA.

Bury NR \& Sturm A 2007 Evolution of the corticosteroid receptor signalling pathway in fish. General and Comparative Endocrinology 153 47-56. (doi:10.1016/j.ygcen.2007.03.009)

Carragher JF \& Sumpter JP 1990 The effect of cortisol on the secretion of sex steroids from cultured ovarian follicles of rainbow trout. General and Comparative Endocrinology 77 403-407. (doi:10.1016/00166480(90)90230-J)

Carré JM \& Mehta PH 2011 Importance of considering testosteronecortisol interactions in predicting human aggression and dominance. Aggressive Behavior 37 489-491. (doi:10.1002/ab.20407)

Casas L, Saborido-Rey F, Ryu T, Michell C, Ravasi T \& Irigoien X 2016 Sex change in clownfish: molecular insights from transcriptome analysis. Scientific Reports 6. (doi:10.1038/srep35461)

Chang J \& Peter R 1984 Influences of norepinephrine and $\alpha$-adrenergic mechanisms on gonadotropin secretion in female goldfish, Carassius auratus. General and Comparative Endocrinology 55 89-95. (doi:10.1016/0016-6480(84)90132-1)

Coe WR 1943 Sexual differentiation in mollusks. I. Pelecypods. Quarterly Review of Biology 18 154-164. (doi:10.1086/394673)

Consten D, Lambert JGD, Komen H \& Goos HJT 2002 Corticosteroids affect the testicular androgen production in male common carp (Cyprinus carpio L.). Biology of Reproduction 66 106-111. (doi:10.1095/ biolreprod66.1.106)

Contractor RG, Foran CM, Li S \& Willett KL 2004 Evidence of gender- and tissue-specific promoter methylation and the potential for ethinylestradiolinduced changes in Japanese medaka (Oryzias latipes) estrogen receptor and aromatase genes. Journal of Toxicology and Environmental Health, Part A 67 1-22. (doi:10.1080/15287390490253633)

Crudo A, Petropoulos S, Moisiadis VG, Iqbal M, Kostaki A, Machnes Z, Szyf M \& Matthews SG 2012 Prenatal synthetic glucocorticoid treatment changes DNA methylation states in male organ systems: multigenerational effects. Endocrinology 153 3269-3283. (doi:10.1210/ en.2011-2160)

Deveson IW, Holleley CE, Blackburn J, Marshall Graves JA, Mattick JS, Waters PD \& Georges A 2017 Differential intron retention in Jumonji chromatin modifier genes is implicated in reptile temperature-dependent sex determination. Science Advances 3 e1700731. (doi:10.1126/ sciadv.1700731)

Devlin RH \& Nagahama Y 2002 Sex determination and sex differentiation in fish: an overview of genetic, physiological, and environmental influences. Aquaculture 208 191-364. (doi:10.1016/S0044-8486(02)00057-1)

Donaldson ZR \&Young LJ 2008 Oxytocin, vasopressin, and the neurogenetics of sociality. Science 322 900-904. (doi:10.1126/science.1158668)

Dunn E, Kapoor A, Leen J \& Matthews SG 2010 Prenatal synthetic glucocorticoid exposure alters hypothalamic-pituitary-adrenal regulation and pregnancy outcomes in mature female guinea pigs. Journal of Physiology 588 887-899. (doi:10.1113/jphysiol.2009.182139)

Fernandino JI, Hattori RS, Kimura H, Strüssmann CA \& Somoza GM 2008 Expression profile and estrogenic regulation of anti-Müllerian hormone during gonadal development in pejerrey Odontesthes bonariensis, a teleost fish with strong temperature-dependent sex determination. Developmental Dynamics 237 3192-3199. (doi:10.1002/dvdy.21731)

Fernandino JI, Popesku JT, Paul-Prasanth B, Xiong H, Hattori RS, Oura M, Strüssmann CA, Somoza GM, Matsuda M, Nagahama Y et al. 2011 Analysis of sexually dimorphic expression of genes at early gonadogenesis of pejerrey Odontesthes bonariensis using a heterologous microarray. Sexual Development 5 89-101. (doi:10.1159/000324423) 
Fernandino JI, Hattori RS, Kishii A, Strüssmann CA \& Somoza GM 2012 The cortisol and androgen pathways cross talk in high temperatureinduced masculinization: the 11 beta-hydroxysteroid dehydrogenase as a key Enzyme. Endocrinology 153 6003-6011. (doi:10.1210/ en.2012-1517)

Fernandino JI, Hattori RS, Acosta ODM, Strüssmann CA \& Somoza GM 2013 Environmental stress-induced testis differentiation: androgen as a by-product of cortisol inactivation. General and Comparative Endocrinology 192 36-44. (doi:10.1016/j.ygcen.2013.05.024)

Foran CM \& Bass AH 1999 Preoptic GnRH and AVT: axes for sexual plasticity in teleost fish. General and Comparative Endocrinology 116 141-152. (doi:10.1006/gcen.1999.7357)

Frisch A 2004 Sex-change and gonadal steroids in sequentiallyhermaphroditic teleost fish. Reviews in Fish Biology and Fisheries $\mathbf{1 4}$ 481-499. (doi:10.1007/s11160-005-3586-8)

Frisch AJ, Walker SPW, McCormick MI \& Solomon-Lane TK 2007 Regulation of protogynous sex change by competition between corticosteroids and androgens: An experimental test using sandperch, Parapercis cylindrica. Hormones and Behavior 52 540-545. (doi:10.1016/j. yhbeh.2007.07.008)

Gesto M, Soengas J, Rodríguez-Illamola A \& Míguez J 2014 Arginine vasotocin treatment induces a stress response and exerts a potent anorexigenic effect in rainbow trout, Oncorhynchus mykiss. Journal of Neuroendocrinology 26 89-99. (doi:10.1111/jne.12126)

Godwin J 2009 Social determination of sex in reef fishes. Seminars in Cell and Developmental Biology 20 264-270. (doi:10.1016/j. semcdb.2008.12.003)

Godwin J 2010 Neuroendocrinology of sexual plasticity in teleost fishes. Frontiers in Neuroendocrinology 31 203-216. (doi:10.1016/j. yfrne.2010.02.002)

Godwin JR \& Thomas P 1993 Sex change and steroid profiles in the protandrous anemonefish amphiprion melanopus (Pomacentridae, Teleostei). General and Comparative Endocrinology 91 144-157. (doi:10.1006/gcen.1993.1114)

Goos HJT \& Consten D 2002 Stress adaptation, cortisol and pubertal development in the male common carp, Cyprinus carpio. Molecular and Cellular Endocrinology 197 105-116. (doi:10.1016/S03037207(02)00284-8)

Hattori RS, Gould RJ, Fujioka T, Saito T, Kurita J, Strüssmann CA, Yokota M \& Watanabe S 2007 Temperature-dependent sex determination in $\mathrm{Hd}$ rR medaka Oryzias latipes: gender sensitivity, thermal threshold, critical period, and DMRT expression profile. Sexual Development 1 138-146. (doi:10.1159/000100035)

Hattori RS, Fernandino JI, Kishii A, Kimura H, Kinno T, Oura M, Somoza GM, Yokota M, Strüssmann CA \& Watanabe S 2009 Cortisol-induced masculinization: does thermal stress affect gonadal fate in pejerrey, a teleost fish with temperature-dependent sex determination? PLOS ONE $\mathbf{4}$ e6548. (doi:10.1371/journal.pone.0006548)

Hayashi Y, Kobira H, Yamaguchi T, Shiraishi E, Yazawa T, Hirai T, Kamei Y \& Kitano T 2010 High temperature causes masculinization of genetically female medaka by elevation of cortisol. Molecular Reproduction and Development 77 679-686. (doi:10.1002/mrd.21203)

Herpin A \& Schartl M 2015 Plasticity of gene-regulatory networks controlling sex determination: of masters, slaves, usual suspects, newcomers, and usurpators. EMBO Reports 16 1260-1274. (doi:10.15252/embr.201540667)

Holleley CE, O'Meally D, Sarre SD, Graves JAM, Ezaz T, Matsubara K, Azad B, Zhang XW \& Georges A 2015 Sex reversal triggers the rapid transition from genetic to temperature-dependent sex. Nature $\mathbf{5 2 3}$ 79-82. (doi:10.1038/nature14574)

Holleley CE, Sarre SD, O'Meally D \& Georges A 2016 Sex reversal in reptiles: reproductive oddity or powerful driver of evolutionary change? Sexual Development 10 279-287. (doi:10.1159/000450972)

Hu Q, Guo W, Gao Y, Tang R \& Li D 2015 Molecular cloning and characterization of amh and dax 1 genes and their expression during sex inversion in rice-field eel Monopterus albus. Scientific Reports $\mathbf{5}$. (doi:10.1038/srep16667)

Irion U, Krauss J \& Nüsslein-Volhard C 2014 Precise and efficient genome editing in zebrafish using the CRISPR/Cas9 system. Development $\mathbf{1 4 1}$ 4827-4830. (doi:10.1242/dev.115584)
Itoi K, Helmreich DL, Lopez-Figueroa MO \& Watson SJ 1999 Differential regulation of corticotropin-releasing hormone and vasopressin gene transcription in the hypothalamus by norepinephrine. Journal of Neuroscience 19 5464-5472.

Iwata E, Mikami K, Manbo J, Moriya-Ito K \& Sasaki H 2012 Social interaction influences blood cortisol values and brain aromatase genes in the protandrous false clown anemonefish, amphiprion ocellaris. Zoological Science 29 849-855. (doi:10.2108/zsj.29.849)

Jiang J, Wang D, Senthilkumaran B, Kobayashi T, Kobayashi H, Yamaguchi A, Ge W, Young G \& Nagahama Y 2003 Isolation, characterization and expression of 11 beta-hydroxysteroid dehydrogenase type 2 cDNAs from the testes of Japanese eel (Anguilla japonica) and Nile tilapia (Oreochromis niloticus). Journal of Molecular Endocrinology 31 305-315. (doi:10.1677/jme.0.0310305)

Jones GP \& Thompson SM 1980 Social inhibition of maturation in females of the temperate wrasse Pseudolabrus celidotus and a comparison with the blennioid Tripterygion varium. Marine Biology 59 247-256. (doi:10.1007/BF00404748)

Kato Y, Kobayashi K, Watanabe H \& Iguchi T 2011 Environmental sex determination in the branchiopod crustacean Daphnia magna: deep conservation of a doublesex gene in the sex-determining pathway. PLOS Genetics 7 e1001345. (doi:10.1371/journal.pgen.1001345)

Khan IA \& Thomas P 1996 Melatonin influences gonadotropin II secretion in the Atlantic croaker (Micropogonias undulatus). General and Comparative Endocrinology $104 \quad 231-242 . \quad$ (doi:10.1006/ gcen.1996.0166)

Kime D 1978 The hepatic catabolism of cortisol in teleost fish-adrenal origin of 11-oxotestosterone precursors. General and Comparative Endocrinology 35 322-328. (doi:10.1016/0016-6480(78)90078-3)

Kitano T, Takamune K, Kobayashi T, Nagahama Y \& Abe S 1999 Suppression of P450 aromatase gene expression in sex-reversed males produced by rearing genetically female larvae at a high water temperature during a period of sex differentiation in the Japanese flounder (Paralichthys olivaceus). Journal of Molecular Endocrinology 23 167-176. (doi:10.1677/jme.0.0230167)

Kitano T, Yoshinaga N, Shiraishi E, Koyanagi T \& Abe SI 2007 Tamoxifen induces masculinization of genetic females and regulates P450 aromatase and Müllerian inhibiting substance mRNA expression in Japanese flounder (Paralichthys olivaceus). Molecular Reproduction and Development 74 1171-1177. (doi:10.1002/mrd.20603)

Kitano T, Hayashi Y, Shiraishi E \& Kamei Y 2012 Estrogen rescues masculinization of genetically female medaka by exposure to cortisol or high temperature. Molecular Reproduction and Development $\mathbf{7 9}$ 719-726. (doi:10.1002/mrd.22080)

Kobayashi Y, Nagahama Y \& Nakamura M 2013 Diversity and plasticity of sex determination and differentiation in fishes. Sexual Development 7 115-125. (doi:10.1159/000342009)

Kusakabe M, Nakamura I \& Young G 2003 11ß-Hydroxysteroid dehydrogenase complementary deoxyribonucleic acid in rainbow trout: cloning, sites of expression, and seasonal changes in gonads. Endocrinology 144 2534-2545. (doi:10.1210/en.2002-220446)

Lamm MS, Liu H, Gemmell NJ \& Godwin JR 2015 The need for speed: Neuroendocrine regulation of socially-controlled sex change. Integrative and Comparative Biology 55 307-322. (doi:10.1093/icb/icv041)

Lepage O, Tottmar O \& Winberg S 2002 Elevated dietary intake of L-tryptophan counteracts the stress-induced elevation of plasma cortisol in rainbow trout (Oncorhynchus mykiss). Journal of Experimental Biology 205 3679-3687.

Levy FO, Ree AH, Eikvar L, Govindan MV, Jahnsen T \& Hansson V 1989 Glucocorticoid receptors and glucocorticoid effects in rat Sertoli cells. Endocrinology 124 430-436. (doi:10.1210/endo-124-1-430)

Liu H 2016 Genomic basis of sex change in fish. PhD Thesis. University of Otago, New Zealand.

Liu H, Lamm MS, Rutherford K, Black MA, Godwin JR \& Gemmell NJ 2015 Large-scale transcriptome sequencing reveals novel expression patterns for key sex-related genes in a sex-changing fish. Biology of Sex Differences 6 307-322. (doi:10.1093/icb/icv041)

Liu H, Todd EV, Lokman PM, Lamm MS, Godwin JR \& Gemmell NJ 2017 Sexual plasticity: a fishy tale. Molecular Reproduction and Development 84 171-194. (doi:10.1002/mrd.22691) 
Lo Nostro F, Grier H, Andreone L \& Guerrero G 2003 Involvement of the gonadal germinal epithelium during sex reversal and seasonal testicular cycling in the protogynous swamp eel, Synbranchus marmoratus Bloch 1795 (Teleostei, Synbranchidae). Journal of Morphology 257 107-126. (doi:10.1002/jmor.10105)

Mankiewicz JL, Godwin J, Holler BL, Turner PM, Murashige R, Shamey R, Daniels HV \& Borski RJ 2013 Masculinizing effect of background color and cortisol in a flatfish with environmental sex-determination. Integrative and Comparative Biology 53 755-765. (doi:10.1093/icb/ ict093)

Matson CK \& Zarkower D 2012 Sex and the singular DM domain: insights into sexual regulation, evolution and plasticity. Nature Reviews Genetics 13 163-174. (doi:10.1038/nrg3161)

Matson CK, Murphy MW, Sarver AL, Griswold MD, Bardwell VJ \& Zarkower D 2011 DMRT1 prevents female reprogramming in the postnatal mammalian testis. Nature 476 101-104. (doi:10.1038/nature10239)

Moczek AP 2015 Developmental plasticity and evolution-quo vadis? Heredity 115 302-305. (doi:10.1038/hdy.2015.14)

Mommsen TP, Vijayan MM \& Moon TW 1999 Cortisol in teleosts: dynamics, mechanisms of action, and metabolic regulation. Reviews in Fish Biology and Fisheries 9 211-268. (doi:10.1023/A:1008924418720)

Moulton JD \& Jiang S 2009 Gene knockdowns in adult animals: PPMOs and vivo-morpholinos. Molecules 14 1304-1323. (doi:10.3390/ molecules14031304)

Munday PL, Wilson White J \& Warner RR 2006 A social basis for the development of primary males in a sex-changing fish. Proceedings Biological Sciences 273 2845-2851. (doi:10.1098/rspb.2006.3666)

Nakamura M \& Kobayashi Y 2005 Sex change in coral reef fish. Fish Physiology and Biochemistry 31 117-122. (doi:10.1007/s10695 -006-7595-x)

Nätt D, Johansson I, Faresjö T, Ludvigsson J \& Thorsell A 2015 High cortisol in 5-year-old children causes loss of DNA methylation in SINE retrotransposons: a possible role for ZNF263 in stress-related diseases. Clinical Epigenetics 7 91. (doi:10.1186/s13148-015-0123-z)

Navarro-Martín L, Vinas J, Ribas L, Diaz N, Gutierrez A, Di Croce L \& Piferrer F 2011 DNA methylation of the gonadal aromatase (cyp19a) promoter is involved in temperature-dependent sex ratio shifts in the European sea bass. PLoS Genetics 7 e1002447. (doi:10.1371/journal. pgen.1002447)

Nepomnaschy PA, Welch KB, McConnell DS, Low BS, Strassmann BI \& England BG 2006 Cortisol levels and very early pregnancy loss in humans. PNAS 103 3938-3942. (doi:10.1073/pnas.0511183103)

Nozu R \& Nakamura M 2015 Cortisol administration induces sex change from ovary to testis in the protogynous Wrasse, Halichoeres trimaculatus. Sexual Development 9 118-124. (doi:10.1159/000373902)

Ospina-Alvarez N \& Piferrer F 2008 Temperature-dependent sex determination in fish revisited: Prevalence, a single sex ratio response pattern, and possible effects of climate change. PLOS ONE 3 e2837. (doi:10.1371/journal.pone.0002837)

Øverli O, Olsen RE, Lovik F \& Ringo E 1999 Dominance hierarchies in Arctic charr, Salvelinus alpinus L.: differential cortisol profiles of dominant and subordinate individuals after handling stress. Aquaculture Research 30 259-264. (doi:10.1046/j.1365-2109.1999.00322.x)

Øverli Ø, Harris CA \& Winberg S 2000 Short-term effects of fights for social dominance and the establishment of dominant-subordinate relationships on brain monoamines and cortisol in rainbow trout. Brain, Behavior and Evolution 54 263-275. (doi:10.1159/000006627)

Ozaki Y, Higuchi M, Miura C, Yamaguchi S, Tozawa Y \& Miura T 2006 Roles of 11 beta-hydroxysteroid dehydrogenase in fish spermatogenesis. Endocrinology 147 5139-5146. (doi:10.1210/en.2006-0391)

Payvar F, DeFranco D, Firestone GL, Edgar B, Wrange Ö, Okret S, Gustafsson J-Å \& Yamamoto KR 1983 Sequence-specific binding of glucocorticoid receptor to MTV DNA at sites within and upstream of the transcribed region. Cell 35 381-392. (doi:10.1016/00928674(83)90171-X)

Perry AN \& Grober MS 2003 A model for social control of sex change: interactions of behavior, neuropeptides, glucocorticoids, and sex steroids. Hormones and Behavior 43 31-38. (doi:10.1016/S0018506X(02)00036-3)

Pfennig F, Standke A \& Gutzeit HO 2015 The role of Amh signaling in teleost fish-Multiple functions not restricted to the gonads. General and Comparative Endocrinology $223 \quad 87-107 . \quad$ (doi:10.1016/j. ygcen.2015.09.025)

Poonlaphdecha S, Pepey E, Canonne M, de Verdal H, Baroiller JF \& D'Cotta H 2013 Temperature induced-masculinisation in the Nile tilapia causes rapid up-regulation of both dmrt1 and amh expressions. General and Comparative Endocrinology 193 234-242. (doi:10.1016/j. ygcen.2013.06.007)

Relkin R 1989 Pineal response in the cichlid fish Oreochromis mossambicus to extreme osmolality, $\mathrm{pH}$, and temperature. Journal of Pineal Research 7 37-43. (doi:10.1111/j.1600-079X.1989.tb00440.x)

Ribas L, Liew WC, Díaz N, Sreenivasan R, Orbán L \& Piferrer F 2017 Heat-induced masculinization in domesticated zebrafish is familyspecific and yields a set of different gonadal transcriptomes. PNAS $\mathbf{1 1 4}$ 6. (doi:10.1073/pnas.1609411114)

Robertson DR \& Choat JH 1974 Protogynous hermaphroditism and social systems in labrid fish. Proceedings of the Second International Coral Reef Symposium 1 217-225.

Rodríguez-Marí A, Yan Y-L, BreMiller RA, Wilson C, Cañestro C \& Postlethwait JH 2005 Characterization and expression pattern of zebrafish Anti-Müllerian hormone (Amh) relative to sox9a, sox9b, and cyp19a1a, during gonad development. Gene Expression Patterns 5 655667. (doi:10.1016/j.modgep.2005.02.008)

Ryan J, Ludbrook L, Wilhelm D, Sinclair A, Koopman P, Bernard P \& Harley V 2011 Analysis of gene function in cultured embryonic mouse gonads using nucleofection. Sexual Development 5 7-15. (doi:10.1159/000322162)

Sarre SD, Georges A \& Quinn A 2004 The ends of a continuum: genetic and temperature-dependent sex determination in reptiles. Bioessays $\mathbf{2 6}$ 639-645. (doi:10.1002/bies.20050)

Sarre SD, Ezaz T \& Georges A 2011 Transitions between sexdetermining systems in reptiles and amphibians. Annual Review of Genomics and Human Genetics 12 391-406. (doi:10.1146/annurevgenom-082410-101518)

Sax L 2002 How common is intersex? A response to Anne Fausto-Sterling. Journal of Sex Research 39 174-178. (doi:10.1080/00224490209552139)

Schulz R 1986 In vitro metabolism of steroid hormones in the liver and in blood cells of male rainbow trout (Salmo gairdneri Richardson). General and Comparative Endocrinology 64 312-319. (doi:10.1016/00166480(86)90019-5)

Selim KM, Shinomiya A, Otake H, Hamaguchi S \& Sakaizumi M 2009 Effects of high temperature on sex differentiation and germ cell population in medaka, Oryzias latipes. Aquaculture 289 340-349. (doi:10.1016/j.aquaculture.2008.12.019)

Senthilkumaran B, Okuzawa K, Gen K \& Kagawa H 2001 Effects of serotonin, GABA and neuropeptide $Y$ on seabream gonadotropin-releasing hormone release in vitro from preoptic-anterior hypothalamus and pituitary of red seabream, Pagrus major. Journal of Neuroendocrinology 13 395-400. (doi:10.1046/j.1365-2826.2001.00645.x)

Shao CW, Li QY, Chen SL, Zhang P, Lian JM, Hu QM, Sun B, Jin LJ, Liu SS, Wang ZJ et al. 2014 Epigenetic modification and inheritance in sexual reversal of fish. Genome Research 24 604-615. (doi:10.1101/ gr.162172.113)

Shapiro DY 1979 Social behavior, group structure, and the control of sex reversal in hermaphroditic fish. Advances in the Study of Behavior 10 43-102. (doi:10.1016/S0065-3454(08)60093-5)

Shinoda T, Miranda LA, Okuma K, Hattori RS, Fernandino JI, Yoshizaki G, Somoza GM \& Strüssmann CA 2010 Molecular cloning and expression analysis of Fshr and Lhr in relation to Fshb and Lhb subunits during the period of temperature-dependent sex determination in pejerrey Odontesthes bonariensis. Molecular Reproduction and Development 77 521-532. (doi:10.1002/mrd.21179)

Solomon-Lane TK, Crespi EJ \& Grober MS 2013 Stress and serial adult metamorphosis: multiple roles for the stress axis in socially regulated sex change. Frontiers in Neuroscience 7 210. (doi:10.3389/ fnins.2013.00210)

Stelkens RB \& Wedekind C 2010 Environmental sex reversal, Trojan sex genes, and sex ratio adjustment: conditions and population consequences. Molecular Ecology 19 627-646. (doi:10.1111/j.1365294X.2010.04526.x)

Sun L-X, Wang Y-Y, Zhao Y, Wang H, Li N \& Ji XS 2016 Global DNA methylation changes in Nile tilapia gonads during high temperature- 
induced masculinization. PLoS ONE 11 1. (doi:10.1371/journal. pone.0169380)

Szyf M 2005 DNA methylation and demethylation as targets for anticancer therapy. Biochemistry 70 533-549. (doi:10.1007/s10541-005-0147-7)

Tanaka M, Saito D, Morinaga C \& Kurokawa H 2008 Cross talk between germ cells and gonadal somatic cells is critical for sex differentiation of the gonads in the teleost fish, medaka (Oryzias latipes). Development, Growth and Differentiation $\mathbf{5 0}$ 273-278. (doi:10.1111/j.1440169X.2008.01015.x)

Todd EV, Liu H, Muncaster S \& Gemmell NJ 2016 Bending genders: the biology of natural sex change in fish. Sexual Development 10 223-241. (doi:10.1159/000449297)

Todo T, Sato M, Ashida M, Yamaguchi N, Kobayashi Y, Adachi S, Yamauchi K \& Nakamura M 2008 In vitro induction of gonadal sex change in a protogynous fish, three-spotted wrasse (Halichoeres trimaculatus). Cybium: International Journal of Ichthyology 32106.

Vanyushin BF, Nemirovsky LE, Klimenko VV, Vasiliev VK \& Belozersky AN 1973 The 5-methylcytosine in DNA of rats. Gerontology 19 138-152. (doi:10.1159/000211967)

Viau V 2002 Functional cross-talk between the hypothalamic-pituitarygonadal and -adrenal axes. Journal of Neuroendocrinology 14 506-513. (doi:10.1046/j.1365-2826.2002.00798.x)

Vizziano D, Baron D, Randuineau G, Mahè S, Cauty C \& Guiguen Y 2008 Rainbow trout gonadal masculinization induced by inhibition of estrogen synthesis is more physiological than masculinization induced by androgen supplementation. Biology of Reproduction 78 939-946. (doi:10.1095/biolreprod.107.065961)

Wang X \& Orban L 2007 Anti-Müllerian hormone and $11 \beta$-hydroxylase show reciprocal expression to that of aromatase in the transforming gonad of zebrafish males. Developmental Dynamics 236 1329-1338. (doi:10.1002/dvdy.21129)

Warner RR 1984 Mating-behavior and hermaphroditism in coral-reef fishes. American Scientist 72 128-136.

Warner RR 1988 Sex change and the size-advantage model. Trends in Ecology and Evolution 3 133-136. (doi:10.1016/0169-5347(88)90176-0)

Warner RR \& Swearer SE 1991 Social control of sex change in the bluehead wrasse thalassoma bifasciatum (Pisces: Labridae). Biological Bulletin 181 199-204. (doi:10.2307/1542090)

Wen AY, You F, Sun P, Li J, Xu DD, Wu ZH, Ma DY \& Zhang PJ 2014 CpG methylation of dmrt1 and cyp19a promoters in relation to their sexual dimorphic expression in the Japanese flounder Paralichthys olivaceus. Journal of Fish Biology 84 193-205. (doi:10.1111/jfb.12277)

Wendelaar Bonga SE 1997 The stress response in fish. Physiological Reviews 77 591-625.

Whirledge S \& Cidlowski JA 2010 Glucocorticoids, stress, and fertility. Minerva Endocrinologica 35 109-125.
Wilhelm D \& Koopman P 2006 The makings of maleness: towards an integrated view of male sexual development. Nature Reviews Genetics 7 620-631. (doi:10.1038/nrg1903)

Windley SP \& Wilhelm D 2015 Signaling pathways involved in mammalian sex determination and gonad development. Sexual Development $\mathbf{9}$ 297-315. (doi:10.1159/000444065)

Yamaguchi T \& Kitano T 2012 High temperature induces cyp26b1 mRNA expression and delays meiotic initiation of germ cells by increasing cortisol levels during gonadal sex differentiation in Japanese flounder. Biochemical and Biophysical Research Communications 419 287-292. (doi:10.1016/j.bbrc.2012.02.012)

Yamaguchi T, Yoshinaga N, Yazawa T, Gen K \& Kitano T 2010 Cortisol is involved in temperature-dependent sex determination in the Japanese flounder. Endocrinology 151 3900-3908. (doi:10.1210/ en.2010-0228)

Yamamoto Y, Zhang Y, Sarida M, Hattori RS \& Strüssmann CA 2014 Coexistence of genotypic and temperature-dependent sex determination in pejerrey Odontesthes bonariensis. PLOS ONE 9 e102574. (doi:10.1371/ journal.pone.0102574)

Yoshinaga N, Shiraishi E, Yamamoto T, Iguchi T, Abe S-I \& Kitano T 2004 Sexually dimorphic expression of a teleost homologue of Müllerian inhibiting substance during gonadal sex differentiation in Japanese flounder, Paralichthys olivaceus. Biochemical and Biophysical Research Communications 322 508-513. (doi:10.1016/j.bbrc.2004.07.162)

Yu K, Rosenblum P \& Peter R 1991 In vitro release of gonadotropinreleasing hormone from the brain preoptic-anterior hypothalamic region and pituitary of female goldfish. General and Comparative Endocrinology 81 256-267. (doi:10.1016/0016-6480(91)90010-4)

Yuan HW, Chen F, Xu QQ, Gong SY, Yu DH \& Yang DQ 2012 Effects of exogenous melatonin on serum steroid hormones, GSI, survival ratio and sex reversal in rice field eel (Monopterus albus). Applied Mechanics and Materials 142 238-242. (doi:10.4028/www.scientific. net/AMM.142.238)

Zhang Y, Zhang S, Liu Z, Zhang L \& Zhang W 2013 Epigenetic modifications during sex change repress gonadotropin stimulation of cyp19a1a in a teleost ricefield eel (Monopterus albus). Endocrinology 154 2881-2890. (doi:10.1210/en.2012-2220)

Received 6 July 2017

First decision 14 August 2017

Revised manuscript received 24 August 2017

Accepted 8 September 2017 